\title{
Judging causes of soil degradation and remedial measures for reclamation in Kaithal district of Haryana state
}

\begin{abstract}
Aditya
College of Agriculture, CCS Haryana Agricultural University, Hisar-125004 (Haryana), India

Nidhi Sharma*

Department of Extension Education, CCS Haryana Agricultural University, Hisar-125004 (Haryana), India

P.S. Shehrawat

Department of Extension Education, CCS Haryana Agricultural University, Hisar-125004 (Haryana), India

*Corresponding author. E- mail: nidhisharma1260@gmail.com

Abstract

Soil degradation is a point of evolution which leads to a reduction of resource potential. About $7.40 \mathrm{~m}$ ha arable lands globally turn to degraded lands as a result of climate change and deforestation. The problem of soil degradation has been ever since cultivation of soils started because of increasing population of India at the rate of about $1.8 \%$ requiring marginal areas to be brought under the plough to meet the growing food demand. The present study was conducted in Kaithal district in the year 2018-19. The study revealed that 'Excessive use of chemical fertilizers' (88.33\%) followed by 'non- judicious use of insecticides/pesticides' (85.83\%), 'less application of organic manure' $(85.00 \%)$, 'deforestation $(78.33 \%)$, and 'over uplifting of ground water' $(75.83 \%)$ were found as most important causes of soil degradation. The most important remedial action for problematic soil were found as 'land for equal distribution of resources/irrigation' $(90.83 \%)$ followed by 'application of Gypsum for sodic and saline soil' (85.83\%), 'introduction of legumes in cropping system' $(80.00 \%)$, 'recharge of ground water during rainy season' $(78.33 \%)$, 'crop residue incorporation by happy seeder' $(77.50 \%)$, 'application of green manuring/ organic manure' $(75.00 \%)$ and 'leaching of salts in saline soil' $(72.50 \%)$. Soil conservation is important for the future use and future generation. The study would be helpful in soils conservation which may otherwise cause damage to plant growth which in turn may adversely affect yield and there by food security also.
\end{abstract}

Keywords: Climate change, Deforestation, Organic manure and Soil degradation

\section{Article Info}

https://doi.org/

10.31018/jans.v11i4.2183

Received: October 30, 2019

Revised: November 28, 2019

Accepted: December 1, 2019

\section{How to Cite}

Aditya, et al. (2019). Judging causes of soil degradation and remedial measures for reclamation in Kaithal district of Haryana state. Journal of Applied and Natural Science, 11 (4): 802 - 805 https:// doi.org/10.31018/ jans.v11i4.2183

\section{INTRODUCTION}

Land is a non-renewable resource which is vital for all primary production systems. Pastures and crops are the two most extensive forms of land use, occupying $25 \%$ and $12 \%$ of the global land surface, respectively (Ramankutty and Foley, 1999; Asner et al., 2004). As far as agricultural land is concerned, per capita land has declined from 0.48 hectare in 1951 to 0.16 hectare in 1991 and is likely to decline further to 0.08 hectare in 2035 (Yadav, 2000 and Nagaraja, 2009). Soil or land degradation which causes decline in soil's productivity, deterioration in vegetative cover, qualitative and quantitative decline of soil and water resources and pollution of air is rampant in India. It is estimated that out of 329 million hectare total geographical area of India, the area under agriculture is $179.9 \mathrm{M}$ ha and 120.4 million hectarearea is degraded through one or more degradation types, which in turn, is affecting the country's productive resource base. It has been estimated a total of more than 5000 tonnes of top soil is being eroded every year. Of about 1600 million tonnes representing $30 \%$ of the total eroded area is permanently getting lost to the sea. The main causes of degradation are due to direct/ indirect human intervention (Aulakh et al., 2015). Bush burning has been adopted by most farmers in northern Ghana for clearing land for cultivationannually, because of its ease and convenience. This exposes the surface soil layer to destruction.Higher infiltration rates were measured on burnt soils as compared to un-burnt soils and burning exerts some effects on soil physical and chemical properties(Salifu et al., 2013).Urgent measures are required to arrest the degradation process and to restore productivity of degraded soils so that more food could be produced to provide livelihood and environmental security to the 
Aditya, et al. / J. Appl. \& Nat. Sci. 11(4): 802 - 805 (2019)

increasing Indian population. This requires the systematic knowledge on the soils, characterization of basic resources like soil, water, climate and biodiversity problems and potentials for optimizing land use. Various remedies for reclamation should be put forward to restore the degradation of soil. Keeping these above facts in mind this study was undertaken to know the "causes of soil degradation and remedies for reclamation in Kaithal district".

\section{MATERIALS AND METHODS}

The present study on judging causes of soil degradation and remedial measures for reclamation in Kaithal district was conducted in Haryana state in 2018-19. Kaithal district was selected randomly. These villages namely Dherdu, Faral, Guhida, Bindrana, Jadaula, Siwan, Teontha, Rasina, Fatehpur, Mundri, MatrawaKheri, Teak, Anhu, Geong, Batta, Jajanpur, Khanoda, Peoda, Devigarh, Shergarh, and KheriSakra were selected purposively, where RAWE program of BSc (Hons) Agri. final year students were organized. One hundred and twenty respondents were selected randomly and they were personally interviewed with help of interview schedule specially prepared for this study. The statistical measures like mean, frequency, percentage and rank orders were used to draw meaningful inferences (Singh et al, 2012 a).

\section{RESULTS AND DISCUSSION}

Table 1 indicates that majority of respondents $(88.33 \%)$ said that excessive use of chemical fertilizers is most important cause of soil degradation followed by non- judicious use of insecticides/ pesticides $(85.83 \%)$, less application of organic manure $(85.00 \%)$, deforestation $(78.33 \%)$, over uplifting of ground water $(75.83 \%)$, while on the other hand majority of respondents said that population growth is most important indirect cause of soil degradation $(85.00 \%)$ followed by intensive cultivation due to land shortage and land fragmentation $(81.66 \%)$, poor access to advisory services $(76.66 \%)$ and climate change $(75.83 \%)$ were other important causes of soil degradation. The results of the finding are in line with the work of Abdeta (2018) and Bhattacharyya (2015).

Table 2 indicates that majority of respondents $(90.83 \%)$ said that land levelling for equal distribution of resources/irrigation is main remedy for problematic soil followed by application of Gypsum for sodic and saline soil (85.83\%), balance use of fertilizers based on SHC status $(81.66 \%)$,

Table 1. Causes/reasons responsible for soil degradation in Kaithal district of Haryana $(n=120)$.

\begin{tabular}{|c|c|c|c|}
\hline S. $\mathbf{N}$. & Particulars & Yes & No \\
\hline A. & Direct causes/reason & & \\
\hline 1. & Excessive use of chemical Fertilizers & $106(88.33)$ & $14(11.66)$ \\
\hline 2. & Non judicious use of insecticides/pesticides & 103(85.83) & 17(14.16) \\
\hline 3. & Less application of organic manure (FYM or farm manure) & 102(85.00) & $18(15.00)$ \\
\hline 4. & Application of fertilizers without SHC/soil status & $90(75.00)$ & $30(25.00)$ \\
\hline 5. & Non-application of gypsum and lime in soil & $77(64.16)$ & $43(35.84)$ \\
\hline 6. & Intensive cropping system & $89(74.16)$ & $31(25.83)$ \\
\hline 7. & Continuous Mono-cropping system & $90(75.00)$ & $30(25.00)$ \\
\hline 8. & Lack of legume crops introduction in cropping system & $90(75.00)$ & $30(25.00)$ \\
\hline 9. & Straw burning of rice and wheat crop stubble & $87(72.50)$ & $33(27.50)$ \\
\hline 10. & Poor irrigation water & $92(76.66)$ & 28(23.34) \\
\hline 11. & Faulty irrigation method/ Surface (flood) Irrigation & $80(66.66)$ & $40(33.34)$ \\
\hline 12. & Rice based cropping system/ water logging & $80(66.66)$ & $40(33.34)$ \\
\hline 13. & Poor drainage system & $87(72.50)$ & $33(27.50)$ \\
\hline 14. & Over uplifting of ground water & $91(75.83)$ & $29(24.17)$ \\
\hline 15. & Deforestation & $94(78.33)$ & $26(21.67)$ \\
\hline 16. & Heavy tillage exposed the soil carbon to environment & $73(60.83)$ & $47(39.17)$ \\
\hline 17. & Erosion by wind/water & $80(66.66)$ & $40(33.34)$ \\
\hline 18. & Undulated land & $77(64.16)$ & $43(35.84)$ \\
\hline 19. & Increasing salinity and sodicity in soil surface & $82(68.33)$ & $38(31.67)$ \\
\hline 20. & Rising of soil surface underground water table & $72(60.00)$ & 48(40.00) \\
\hline B. & Other causes/reason & & \\
\hline 1. & Intensive cultivation due to land Shortage and land fragmentation & $98(81.66)$ & $22(18.34)$ \\
\hline 2. & Population growth so more pressure on land & $102(85.00)$ & $18(15.00)$ \\
\hline 3. & Limited access to conservation technologies & $86(71.66)$ & $34(28.34)$ \\
\hline 4. & Poor access to advisory services & $92(76.66)$ & $28(23.33)$ \\
\hline 5. & Climate change (Aberrant Monsoon/drought/flooding) & $91(75.83)$ & $29(24.16)$ \\
\hline 6. & Land tenure leads to over exploitation of resources & $83(69.16)$ & $37(30.83)$ \\
\hline 7. & Direct use of industrial effluent as irrigation & $65(54.16)$ & $55(45.84)$ \\
\hline 8. & Use of sewage water without treatment for irrigation & $75(62.50)$ & $55(37.50)$ \\
\hline 9. & Use of saline and sodic underground water for irrigation & $89(74.16)$ & $31(25.84)$ \\
\hline
\end{tabular}

Figures in parenthesis represent percentage 
Table 2. Remedies for reclamation of problematic soil in Kaithal district of Haryana state $(n=120)$.

\begin{tabular}{|c|c|c|c|}
\hline S. N. & Particulars & Effective & Not effective \\
\hline 1. & Permanent soil cover by vegetation & $083(69.16)$ & $37(30.84)$ \\
\hline 2. & Leaching of salts in saline soil & $087(72.50)$ & $33(27.50)$ \\
\hline 3. & Application of Gypsum for sodic and saline soil & 103(85.83) & 17(14.17) \\
\hline 4. & Application of Lime for acidic soils & 097(80.83) & 23(19.17) \\
\hline 5. & Land levelling for equal distribution of resources/irrigation & 109(90.83) & 11(09.17) \\
\hline 6. & Land use configuration & 082(68.33) & $38(31.67)$ \\
\hline 7. & Minimum disturbance of soil/minimum tillage/zero tillage & $084(70.00)$ & $36(30.00)$ \\
\hline 8. & Contour farming for sloppy land & $082(68.33)$ & $38(31.66)$ \\
\hline 9. & Strip cropping with erosion resistant crops & $84(70.00)$ & $36(30.00)$ \\
\hline 10. & Shelter belt and wind break to control wind erosion & $65(54.16)$ & $55(45.84)$ \\
\hline 11. & Field bunding to control water erosion & $67(55.83)$ & $53(44.17)$ \\
\hline 12. & Growing deep rooted plantation in water logged soil & $94(78.33)$ & $26(21.67)$ \\
\hline 13. & Introduction of legumes in cropping system & $96(80.00)$ & $24(20.00)$ \\
\hline 14. & Crop diversification/ crop rotation & $78(65.00)$ & $42(35.00)$ \\
\hline 15. & Application of green manuring/ organic manure & $90(75.00)$ & $30(25.00)$ \\
\hline 16. & Irrigation with good quality water & $95(79.16)$ & $25(20.84)$ \\
\hline 17. & Integrated farming system & $95(79.16)$ & $25(20.84)$ \\
\hline 18. & Balance use of fertilizers based on SHC status & $98(81.66)$ & $22(18.34)$ \\
\hline 19. & Crop residue incorporation by Happy seeder & $93(77.50)$ & $27(22.50)$ \\
\hline 20. & Site specific soil management & $81(67.50)$ & $39(32.50)$ \\
\hline 21. & Furrow irrigated raised bed system & $79(65.83)$ & $41(34.16)$ \\
\hline 22. & Surface mulch (protect from rain drops) & $80(66.66)$ & $40(33.34)$ \\
\hline 23. & Use micro-irrigation method instead of surface irrigation & $69(57.50)$ & $51(42.50)$ \\
\hline 24. & Soil and water testing/Soil health card & $77(64.16)$ & $43(35.84)$ \\
\hline 25. & Adequate drainage system & $88(73.33)$ & $32(26.67)$ \\
\hline 26. & Minimum use of pesticides & $77(64.16)$ & $43(35.84)$ \\
\hline 27. & Salt tolerant crop in problematic soil(barley, cotton and dhaincha) & $91(75.83)$ & $29(24.17)$ \\
\hline 28. & Deep ploughing for salt affecting soil & $86(71.66)$ & $34(28.33)$ \\
\hline 29. & Rain water harvesting & $85(70.83)$ & $35(29.17)$ \\
\hline 30. & Recharge of ground water during rainy season & $94(78.33)$ & $26(21.67)$ \\
\hline 31. & Timely geospatial information on soil requirements & $75(62.50)$ & $45(37.50)$ \\
\hline 32. & Adding of Sulphur and $\mathrm{FeSO}_{4}$ in Alkaline soil & $79(65.83)$ & $41(34.17)$ \\
\hline
\end{tabular}

Figures in parenthesis represent percentage

introduction of legumes in cropping system $(80.00 \%)$, irrigation with good quality water and integrated farming system $(79.16 \%)$, recharge of ground water during rainy season $(78.33 \%)$, crop residue incorporation by happy seeder $(77.50 \%)$, application of green manuring/ organic manure $(75.00 \%)$ and leaching of salts in saline soil $(72.50 \%)$. The results of the study were partially supported by Singh et. al. (2012b) and Rathore et al. (2011) who reported that application of gypsum for sodic and saline soil is main remedy for problematic soil.

\section{Conclusion}

It was concluded that 'Excessive use of chemical fertilizers' (88.33\%) followed by 'non- judicious use of insecticides/pesticides' (85.83\%), 'less application of organic manure' (85.00\%), 'deforestation $(78.33 \%)$, and 'over uplifting of ground water' $(75.83 \%)$ were found as most important causes of soil degradation. The most important remedial action for problematic soil were found as 'land for equal distribution of resources/ irrigation' (90.83\%) followed by 'application of Gypsum for sodic and saline soil' (85.83\%), 'introduction of legumes in cropping sys- tem' $(80.00 \%)$, 'recharge of ground water during rainy season' (78.33\%), 'crop residue incorporation by happy seeder' $(77.50 \%)$, 'application of green manuring/ organic manure' $(75.00 \%)$ and 'leaching of salts in saline soil' $(72.50 \%)$. The work would be helpful in application of remedial action for upgrading the soil leading to increase productivity of crops and fruits.

\section{REFERENCES}

1. Abdeta, G. C. and Geleto, G. M. (2018). Farmers' perception on land degradation and adoption of soilwater conservation measures in ethiopian highlands: Review Article. Journal of Resources Development and Management, 40: 36-54.

2. Asner, G.P., Townsend, A.R., Bustamante, M.M.C., Nardoto, G.B. and Olander, L.P. (2004). Pasture degradation in the central amazon: Linking changes in carbon and nutrient cycling with remote sensing

3. Aulakh, M.S. and Sidhu, G.S. (2015). Soil degradation in India: Causes, major threats, and management options. In: MARCO Symposium 2015 - Next Challenges of Agro-Environmental research in Monsoon Asia. pp. 151-156. National Institute for AgroEnvironmental Sciences (NIAES), Tsukuba, Japan.

4. Bhattacharyya, R., Ghosh, B. N., Mishra, P. K. and Mandal, B. (2015). Soil Degradation in India: Chal- 
Aditya, et al. / J. Appl. \& Nat. Sci. 11(4): 802 - 805 (2019)

lenges and Potential Solutions. Sustainability. 7(4): 3528-3570.

5. Nagaraja, B.C. (2009). $2^{\text {nd }}$ German-Indian Conference on Research for Sustainability. United Nations University, Bonn, 27-28 April, 2009.

6. Ramankutty, N. and Foley, J.A. (1999). Estimating historical changes in land- cover: North American cropland from 1700 to 1992. Global Biogeochemical cycles, 13: 997-1027.

7. Rathore, K. P. S., Bangarva, G. S., Rathore, R. S., Ranawat, R. and Rathore, D. P. S. (2011). Training needs of opium growers in pratapgarh district of Rajasthan. Rajasthan Journal of Extension Education. 19: 202-205.

8. Salifu, T., Agyare, W.A., Boamah, P.O., Jacqueline, O. and Naabil, E. (2013). Assessment of the Effect of
Burning on Soil Properties in the Guinea Savannah Zone of Ghana. International Journal of Agriculture Innovations and Research, 2 (3): 313-316.

9. Singh, P.R., Singh, S., Singh, A. and Chaudhary, S.P. (2012a). Reclamation of degraded land through forestry practices.https://www.researchgate.net/ publication/288107796

10.Singh, S., Khaddar, V. K, Ahirwar, R. P. and Leelavati. (2012b). Crop Productivity and Training Needs of Beneficiary Farmers in Watershed Development Programme. Indian Research Journal of Extension Education. 1: 303-306.

11.Yadav, J.S.P. (2000). Advances in Land Resource Management for $21^{\text {st }}$ Century. Soil conservation society of India, 253-264. 